decade after the publication in English of Between Facts and Norms (Habermas, 1996). Everyone working in the social sciences in this era where normative questions regarding the validity of democracy have taken centre stage and when the problems of rationality and universality have not been resolved, would benefit from reading this book.

\title{
References
}

Habermas, J. (1994) 'Struggles for recognition in the democratic constitutional state', in C. Taylor (ed.) Multiculturalism: Examining the Politics of Recognition, Princeton: Princeton University Press.

Habermas, J. (1996) Between Facts and Norms: Contributions to a Discourse Theory of Law and Democracy, Cambridge, MA: MIT Press.

Claire O’Neill

University of Wales, UK

\section{Untimely Politics}

Samuel A. Chambers

Edinburgh University Press, Edinburgh, 2003, ix+196pp.

ISBN: 0748617663.

Contemporary Political Theory (2005) 4, 101-103. doi:10.1057/palgrave.cpt.9300164

This is an excitingly disruptive book. It offers a substantial thesis in philosophy and then employs it productively. It is lucid, argumentative and topical. It wastes no words. Perhaps the author should challenge himself with producing an illustrated or multi-media version, but other than that, he has mastered the material.

The project of the book, signalled by 'untimely' in the title, is to displace linear or progressive concepts of either the individual or of history. While 'discursive practices always prove to be saturated by history', they 'can never be understood to move in history in a linear, cyclical or any other predictable pattern' (p. 164). The obvious genealogy is to Foucault and Nietzsche, and the scholarly and referential aspects of the book are very thoroughly and persuasively handled. The tussle in the book is whether this outlook depoliticizes thought and disarms agency, as anti-poststructuralists have claimed. The author's answer is emphatically 'no', in fact, just the opposite.

From the anti-poststructuralist viewpoint, the individual is either fixed in discourse (which 'speaks' him/her) or relativized ('anything goes'). Either way, credible concepts of human agency supposedly go out the 
window. Chambers's reading of poststructuralism and the 'linguistic turn' resists the will to find agency in an instrumental view of language as something to which human beings relate, or which has a relation to human beings. Rather, language is experiential for humanness and resistant to any attempt by them to 'use' it. In that way, it cannot be a test of agency or the lack of it. It isn't something we can know and use independently of it itself, and in that way it cannot control or disempower us. Rather any agency we have is in and through language. This inherent indeterminacy in language (and therefore in the locus of human agency) is figured in the book as spectral or ghostly apparitions, unpredictable, 'out of time', disruptive of history and temporal continuity. Is Hamlet's father dead or not? Does he appear or re-appear? In the context of Chambers's argument, these are nonquestions.

Derrida haunts this text in a similar fashion, as Chambers dialogues with the (un)dead. Butler features as a wayward shade, wandering away from an early productive engagement with Foucault to a later psychologizing and ahistorical unproductive one, asking him the wrong questions and getting disappointing answers. The 'DOMA' laws in the USA ('Defense of Marriage Act') and attendant political debates are brilliantly skewered in the case-study chapter, figuring them as a futile attempt to control the (obviously gender neutral) meaning of 'spouse' (which UK courts have recently enunciated) by fixing it to 'husband' and 'wife', who must be 'man' and 'woman' (respectively). Chambers construes DOMA laws and the proposed Constitutional Amendment as symptomatic of (futile) efforts to fix politics (always already) by attempting to fix language (forever), and to render political judgement certain by this instrumental use of language. Getting a proposed Constitutional Amendment about language as a test case in political philosophy is a bit of a gift for him - it's an excellent chapter, aligning the attention of US Congresspersons to meaning with an explosion of Derridean quotation marks in their own proposals and commentaries.

What's at issue in the book is the (common) presumption that intelligibility and political agency both depend on a (supposed) fixity in linear time and the kind of historicity (whether in conventional narrative history or in studies of intellectual development) that (allegedly) make sensible thought and action possible. Turning these presumptions upside down, Chambers argues that it is precisely those linear and predictable kinds of temporality and historicity that subvert the genuine attention to history, that is, to the historical rather than 'natural' embeddedness of everything, that real-political agency requires. Or to put the matter very simply, if it's historyless it's unchangeable, and if we can know in advance what the future must be, or know always and already what the past must mean, then 
there isn't any room for agency, just for fantasies of control (that never work). While it might sound nonsensical to argue that time isn't linear and that history is indeterminate (and always 'to return'), it isn't. The first 50 pages of Swann's Way should tell anyone that. Rather this insight merely mirrors the properties of language through which time and history are experienced linguistically in the first place.

The chapter on how to have a theory of language that is necessarily within language (and yet not) is a subtle reading (and rescue) of Heidegger, with which I would not presume to quarrel. Substantially, Chambers argues that much of philosophy treats language AIO ('as if objectified'), which he identifies as an incoherent and disabling view of things. While no philosophical view is ever going to put the world right just like that, I have to say that I am intrigued with this one, precisely since it's such a thorough inversion of so much certainty and such a careful celebration of indeterminacy. As in language, so in life. If you think Nietzsche is dangerous and should be stopped (an untimely thought), then this book is not for you. However, if you suspect that tarring poststructuralists with the brush of philosophical determinism and political paralysis doesn't really work, then this book will tell you why you're right.

Terrell Carver University of Bristol, UK

\section{The Philosophy of Oakeshott}

Terry Nardin

Pennsylvania State University Press, University Park, PA, 2001, $x+241 p p$. ISBN: $027102156 \mathrm{X}$.

Contemporary Political Theory (2005) 4, 103-105. doi:10.1057/palgrave.cpt.9300172

Michael Oakeshott is still usually thought of as a political thinker, a political theorist or an historian of political thought. This is of course not false. He was all of these things, but they were not the only thing. He is less often taken seriously as a philosopher, except within the realms of the philosophy of history, where his account of historical experience in Experience and its Modes, 'The Activity of Being an Historian' and On History and other Essays have an honourable place. The starting point for most is still the Oakeshott of Rationalism in Politics or Hobbes's Leviathan or perhaps On Human Conduct. Experience and its Modes is still mentioned more than read and there lurks a corresponding myth that it is an obscure and forbidding work of Hegelian metaphysics, which Oakeshott grew out of once he had written it out of his 